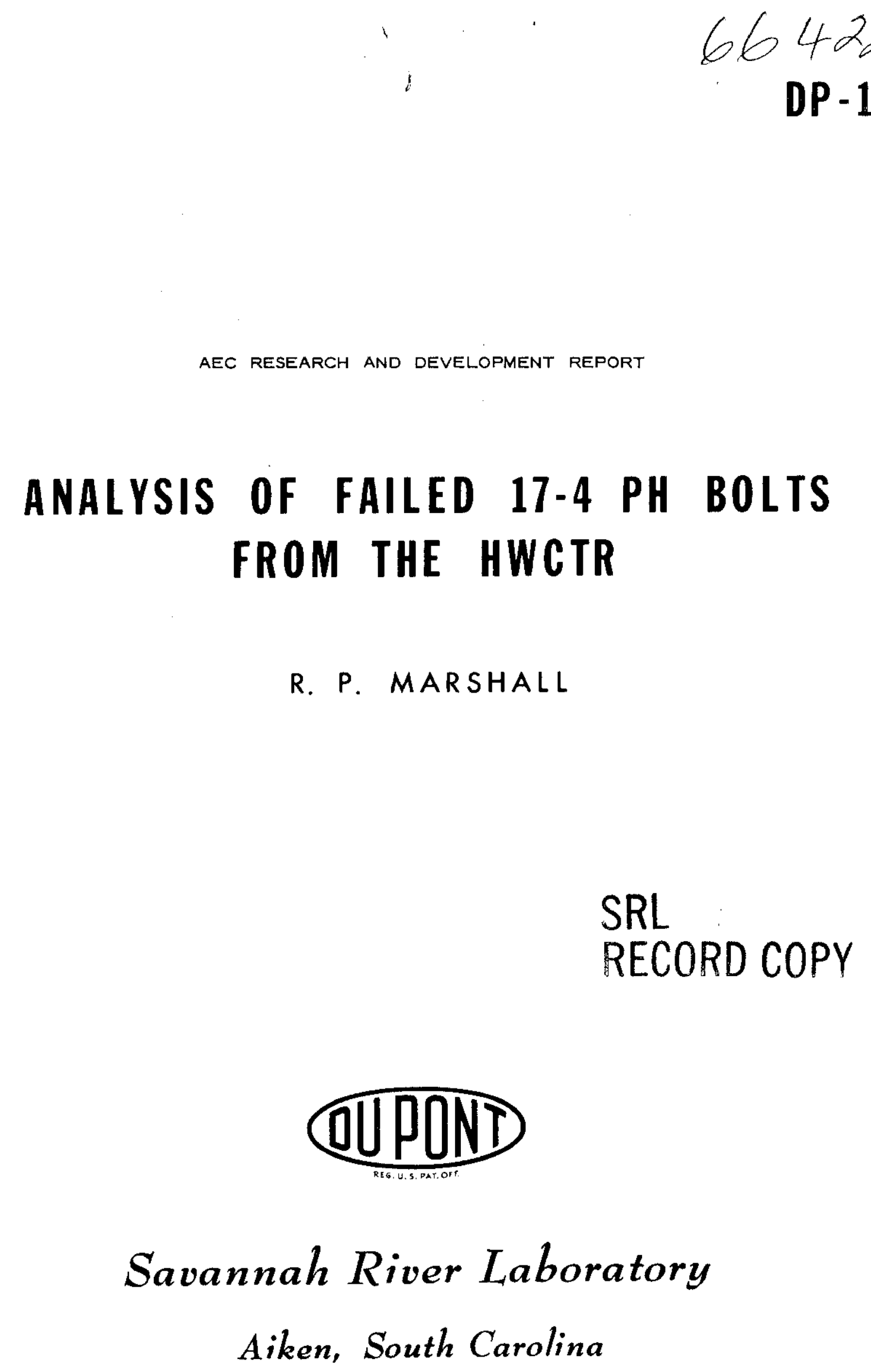




\section{LEGAL NOTICE}

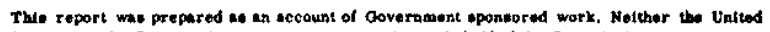

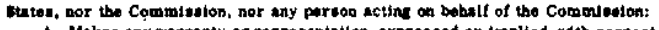

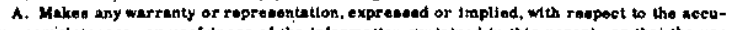

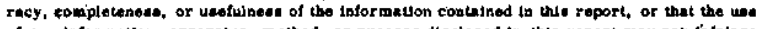
of any informintion, epperatus, method, or process dieclosed in the report may not tintriage privaloly owned riebte; or

B. Ansumes any liablitted with reapeet to the une of, or far demaces reaulting from the of any taformitton, apparatus, method, or procesen disclosed in the raport.

As ueed in the above, "pernon acting on bebsalf of the Commiastion" Includea any omployes or contractor of the commindion, or exployes of euch confractor, to the extent that such omployee or cantractor of the Comnicslon, or employee of auch contractor propares.

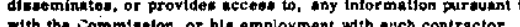

$\therefore$

Printed in the United States of America

Available from

Clearinghouse for Federal Scientific and Technical Information National Bureau of Standards, U. S. Department of Commerce Springfield, Virginia 22151

Price: Printed Copy $\$ 3.00$; Microfiche $\$ 0.65$ 
DP-1102

Metals, Ceramics, and Materlals

(TID-4500)

\title{
ANALYSIS OF FAILED 17-4 PH BOLTS FROM THE HWCTR
}

\author{
by \\ Robert P. MarshalI \\ Approved by \\ P. H. Permar, Research Manager \\ Nuclear Materials Division \\ September 1967
}
E. I. DU PONT DE NEMOURS \& COMPANY SAVANNAH RIVER LABORATORY
AIKEN, S. C. 29801
CONTRACT AT(07-2)-1 WITH THE
UNITED STATES ATOMIC ENERGY COMMISSION




\begin{abstract}
Analysis of flve bolts of 17-4 PH stainless steel from the Heavy Water Components Test Reactor that had falled in service showed that the fallures were inftlated by stress corrosion. In all but one of the falled bolts, an unstable crack size was reached after very little stress corrosion causing fast crack propagation and complete fallure. In one bolt, the stress corrosion crack had stopped growing. Many of the bolts, including all those that falled, were found to have been improperly heat treated to approximately the H925 condition, instead of the specified H1100 condition. The harder H925 condition is conduclve to stress corrosion cracking in this alloy. No evidence for fallure by fatigue was found.
\end{abstract}




\section{CONTENTS}

Page

List of Tables and Flgures ......... . . . . . 4 Introduction .................... . 5

summary ...................... 6

Results and Discussion.............. 7

Description of Gas Baffle Assembly . . . . . . 7

Description of Bolts .............. . 8

Fractography . . . . . . . . . . . . . . II

Metallurgical Condition of Bolts . . . . . . . . 16

Analysis of Applied Stresses . . . . . . . . 18

Conclusions...................... 18

Acknowledgment . . . . . . . . . . . . . 20

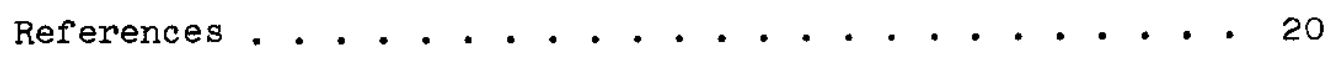




\section{LIST OF TABLES AND FIGURES}

Table

I Chemical Composition of $5 / 8$-inch Bolts . . . . 16

II Hardness of Bolts . . . . . . . . . . . 17

III Behavior of Stressed $17-4 \mathrm{PH}$ Stainless Steel

Samples in the HWCTR . . . . . . . . . 17

Figure

1 Gas Stilling Baffle Assembly . . . . . . . 7

2 Positions of Broken 5/8-inch Bolts. . . . . 8

3 Irradiated $5 / 8$-inch Bolts . . . . . . . . 9

4 Irradiated 3/4-1nch Bolts ......... 10

5 Fracture Surfaces of Falled 5/8-1nch Bolts . . 13

6 Fracture Surfaces of a Failed 3/4-1nch Bolt . . 14

$7 \quad$ Dimpled Rupture and Intergranular Fracture in

5/8-1nch Bolts .............. 15 


\section{INTRODUCTION}

The Heavy Water Components Test Reactor (HWCTR) was operated for the USAEC from March 1962 to December 1964 to test fuel and mechanical components with potential applicability to power reactors moderated and cooled by Iiquid $\mathrm{D}_{2} \mathrm{O}$. The reactor operation was terminated when this program was redirected toward $\mathrm{D}_{2} \mathrm{O}$ reactors cooled by organic liquids.

During an inspection of the interior of the HWCTR reactor vessel in February 1964, two 5/8-inch bolt heads from the support legs of the gas stilling baffle were found on top of the horizontal reactor shield. During removal of the gas baffle assembly for repairs, two more broken $5 / 8$-inch bolts were found. One 3/4-inch bolt was also cracked, and it subsequently falled during removal. The gas baffle had been installed durling startup tests, subsequent to original construction. This assembly contained eight 5/8-inch bolts and $343 / 4$-inch bolts. All of these bolts were of $17-4 \mathrm{PH}$ stainless steel*.

This report gives the results of the detalled examinations and subsequent tests to pinpoint the causes of the bolt failures.

* 17-4 PH refers to a patented, hardenable stainless steel manufactured by Armco Steel Corporation. 


\section{SUMMARY}

The elght 5/8-inch $17-4 \mathrm{PH}$ bolts and the falled $3 / 4$-inch 17-4 PH bolt were much harder than specifled and, thus, had not been properly heat treated.

Stress corrosion of the excessively hardened bolts inltiated cracks, which grew slowly until the applied load was sufficient to cause rapid fracture of the main portion of the bolt. Electron microscopy indicated that the main fractures had occurred by ductile rupture in tension. No evidence of fatigue was found.

Although the stresses on assembly of the bolts are unknown, differential thermal expansion between the bolts and the surrounding 304L material, and intensification of the stresses at thread roots could have produced stresses of approximately 96,000 ps1. Such stresses are sufficient to cause stress corrosion in the improperly heat-treated material during the 276 days of reactor operation prior to discovery of the fallure.

The 17-4 PH bolts were replaced by "Inconel"* $\mathrm{X}$ and AISI 4140 steel, which operated satisfactorily for the remaining 126 days of reactor operation.

* Trademark of the International Nickel Company 


\section{RESULTS AND DISCUSSION}

\section{DESCRIPTION OF GAS BAFFLE ASSEMBLY}

The gas stilling baffle was a circular-shaped plate $1-1 / 4$ inches thick and 50-1/4 inches in diameter that was bolted to a 3/4-1nch-thick baffle support ring, Figure 1 . Both the gas baffle and the support ring were in two sections to facilitate assembly inside the HWCTR vessel, and were bolted together with metal straps. The gas-baffle assembly was supported by four T-shaped support posts that were in turn bolted to the top of the flow-distribution baffle. The gas baffle and baffle-support ring were bolted together and to the top of the support posts with thirty-four 3/4-inch-diameter bolts. The baffle-support posts were bolted to the flow-distribution baffle with elght 5/8-inch diameter bolts. Nothing is known about the initial stresses induced in the bolts during installation. A proprietary thread lubricant subsequently found to contain chlorides may have been used during the installation of the baffle. Thus, chlorides may have contributed to the failures.

All plate material in the gas baffle including the washers was $304 \mathrm{~L}$ stainless steel; all bolts were 17-4 $\mathrm{PH}$.

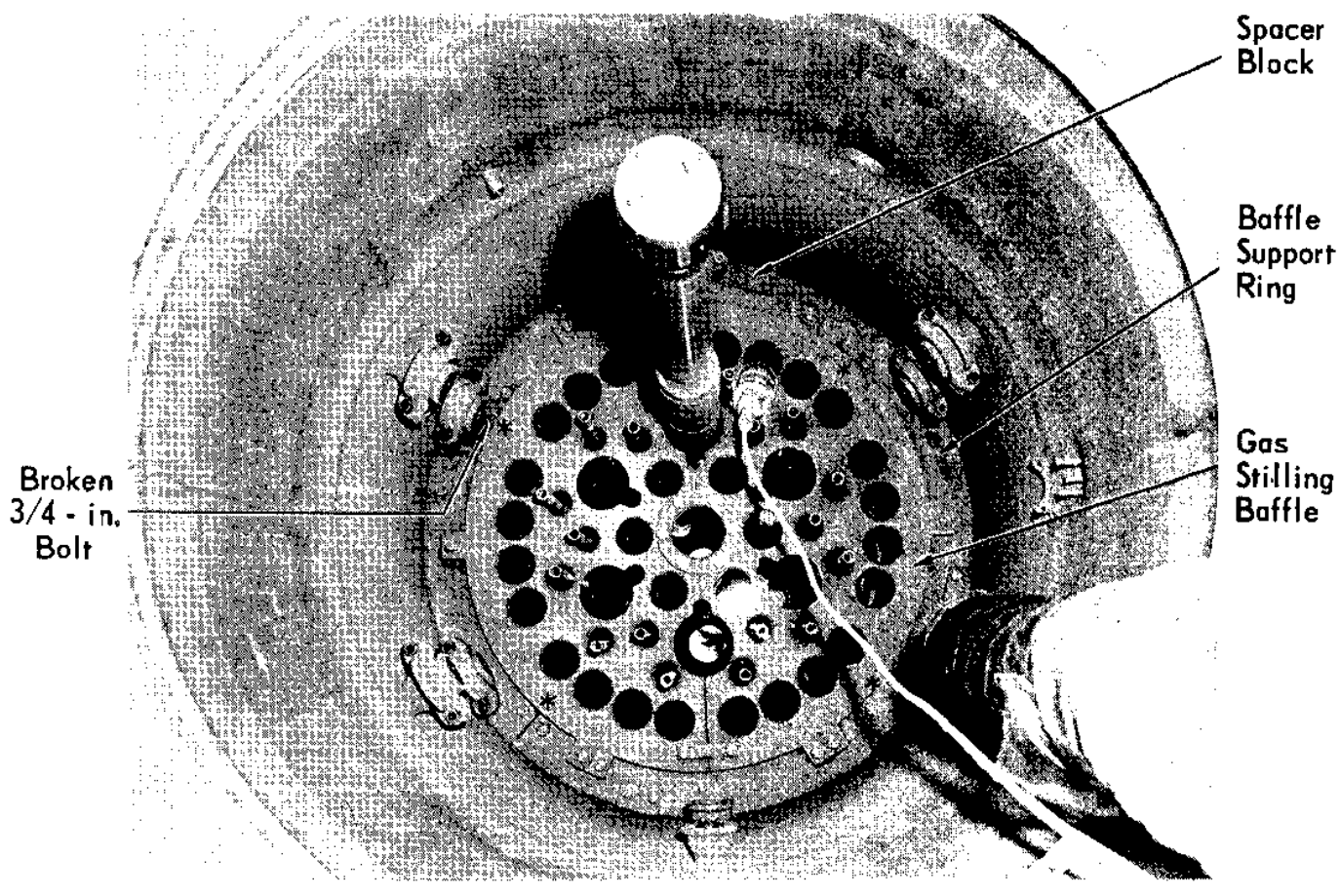

* $3 / 4$ - in. bolts holding baffle support ring to top of support posts

FIG. 1 GAS STILLING BAFFLE ASSEMBLY 


\section{DESCRIPTION OF BOLTS}

The four 5/8-inch bolts that falled were in support posts 1,2 , and 4 of the gas stilling baffle, Figure 2. The two bolts that were found first, $1 A$ and $2 B$, had falled adjacent to the first or second threads from the unthreaded shank, Figure 3 . Bolts $4 \mathrm{~A}$ and $4 \mathrm{~B}$ failed adjacent to the flrst engaged thread. No other cracks were found in the elght $5 / 8$-inch bolts by lowmagnification inspection.

All surfaces of the elght $5 / 8$-inch bolts were covered by a thin, black corrosion film. This film also covered the fracture surfaces of the falled 5/8-inch bolts, and showed that the fractures had occurred some time before they were discovered, which was after about 276 days of reactor operation.

The falled 3/4-inch bolt was located in the top of post 4, position $A$, and held the baffle support ring to the support post. The fracture occurred adjacent to the first engaged thread, Figure 4. This bolt was also covered with the black fllm, but only part of the fracture surface was black. The rest of the fracture surface was light gray, denoting the area that fractured when the bolt was removed during the repalr work.
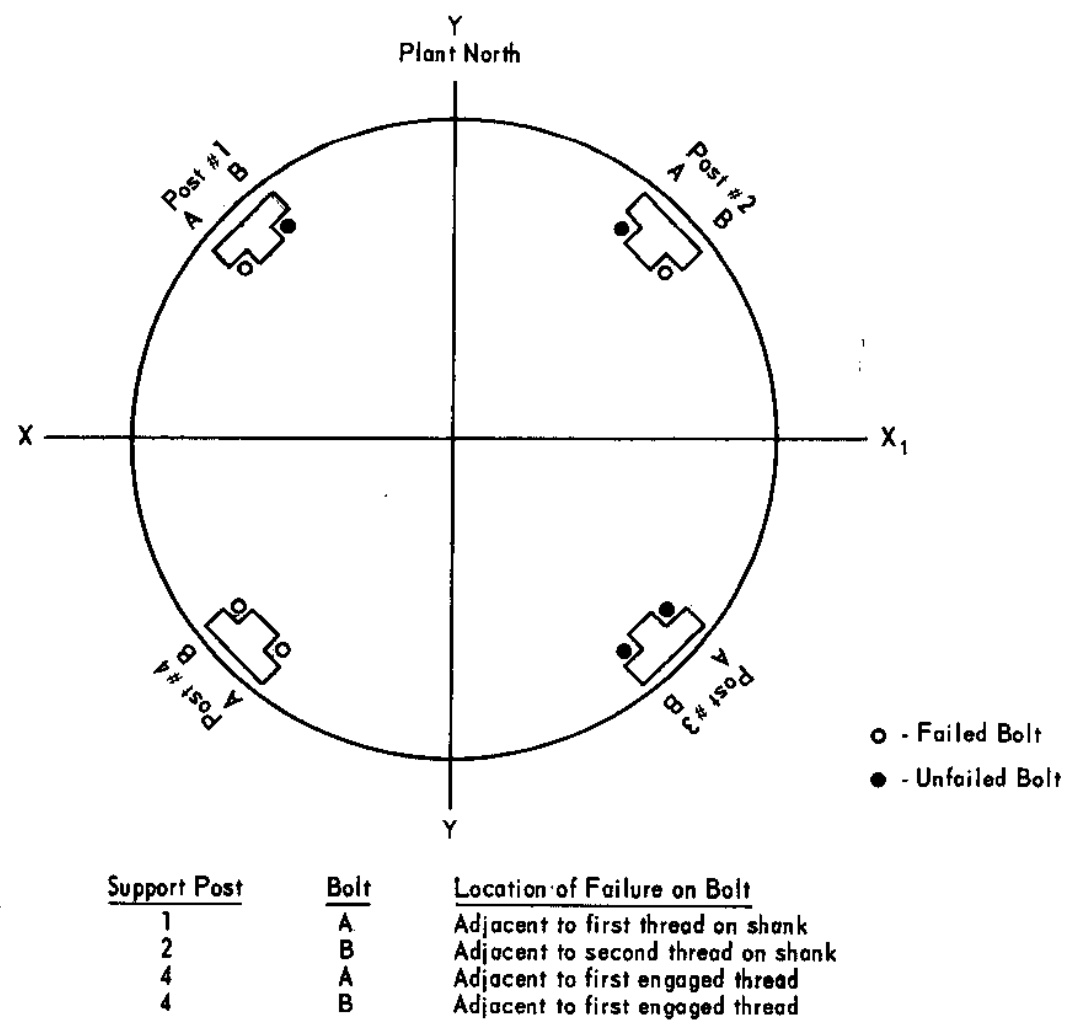

FIG. 2 POSITIONS OF BROKEN 5/8-INCH BOLTS 


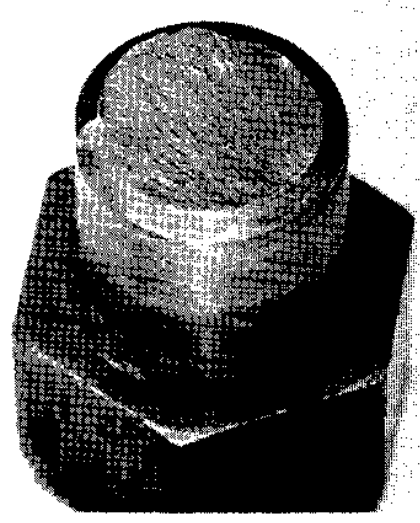

Bolt IA

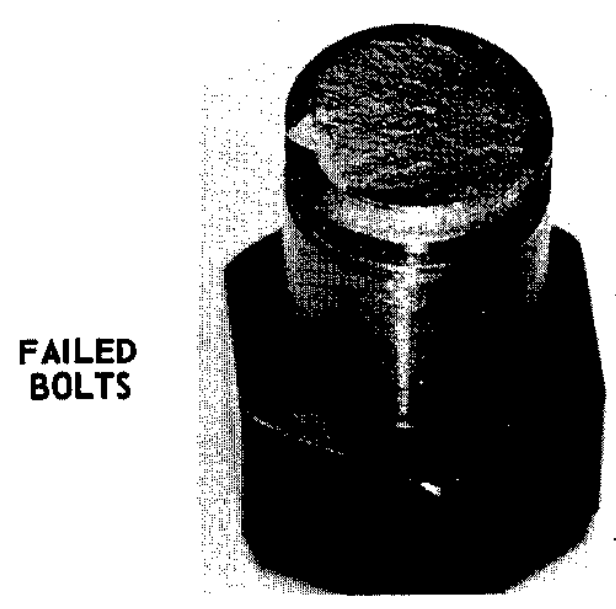

Bolt 2B
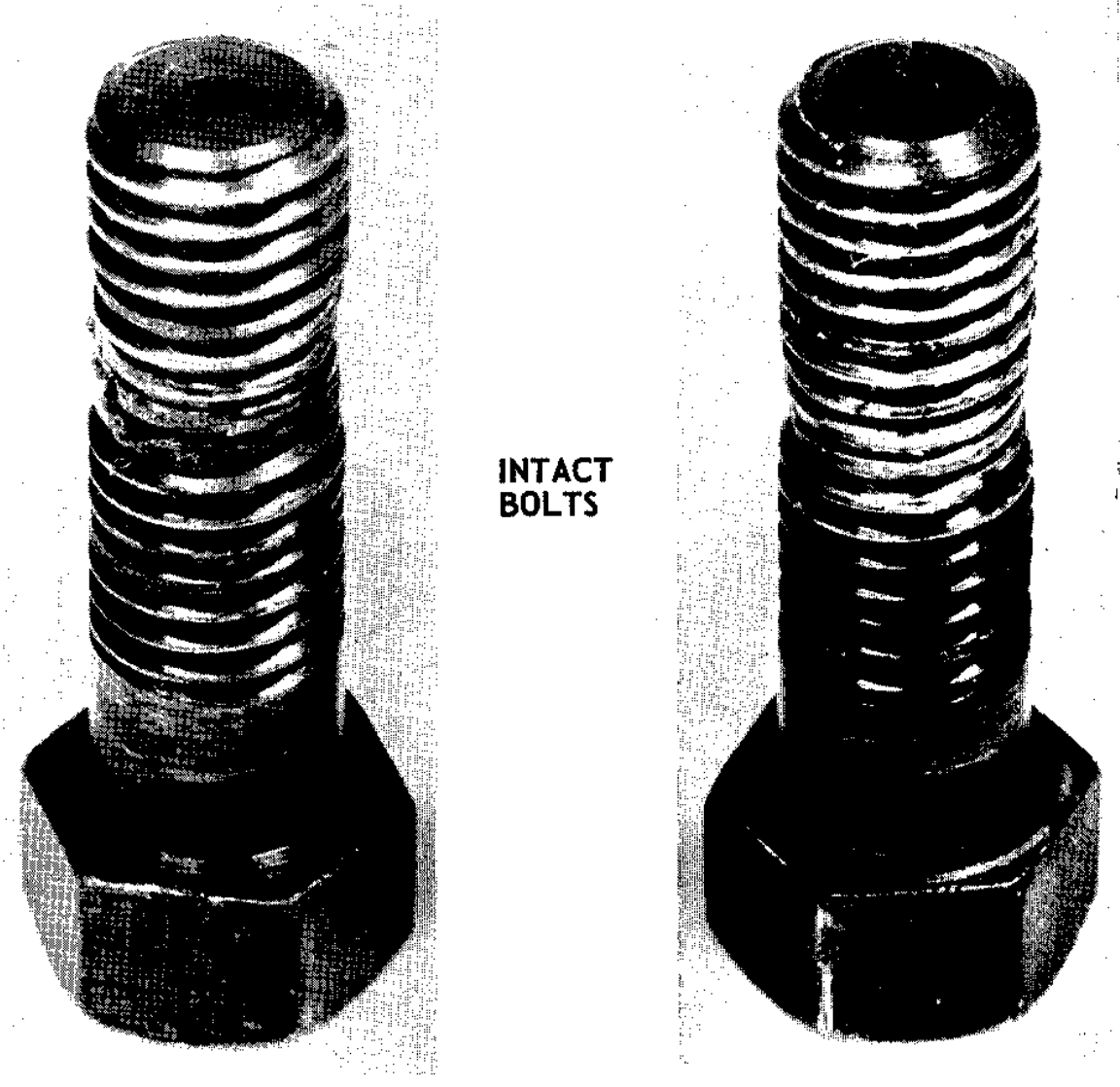

FIG. 3 IRRADIATED $5 / 8$-INCH BOLTS 


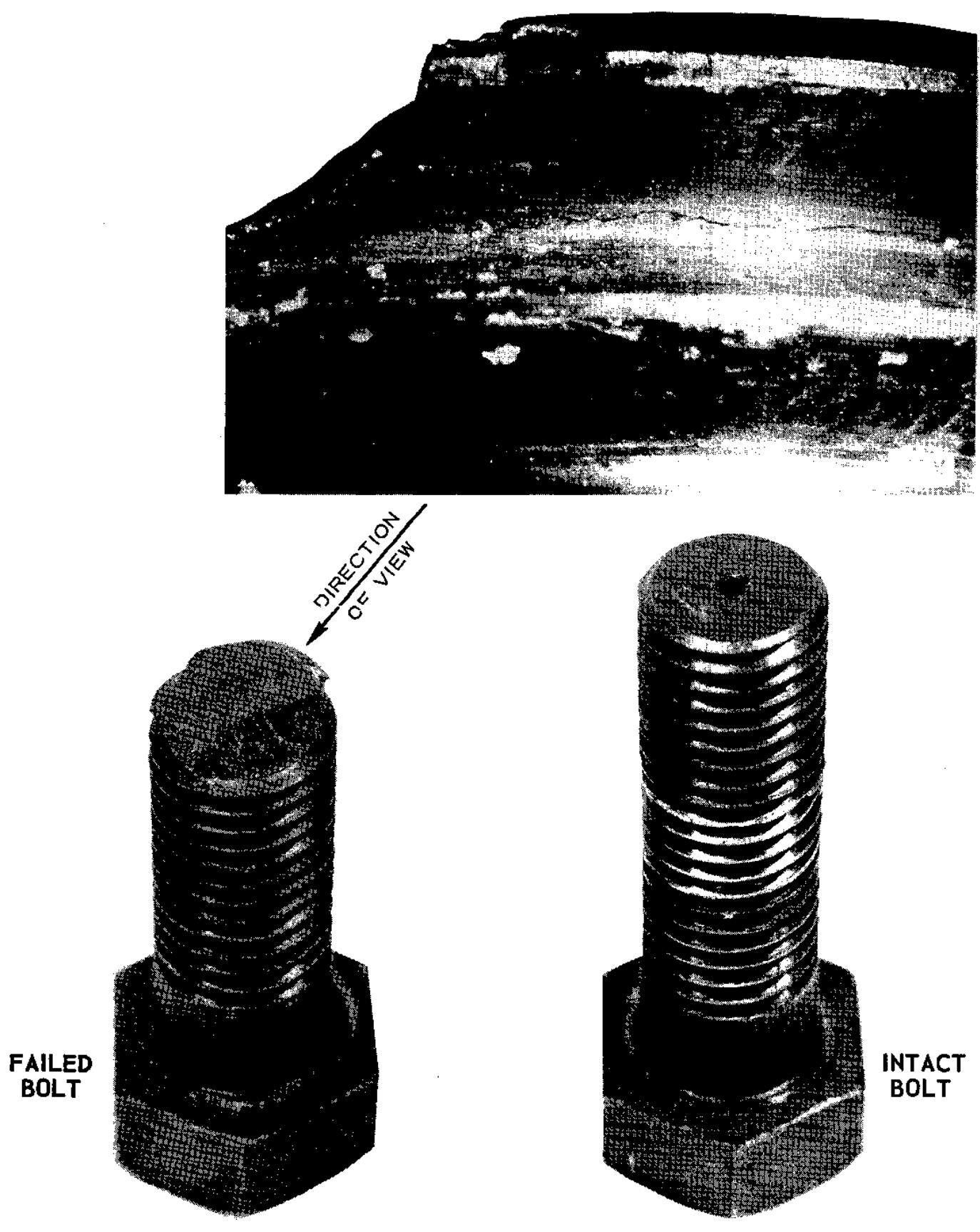

FIG. 4 IRRADIATED 3/4-INCH BOLTS 


\section{FRACTOGRAPHY}

The macroscopic features of the fracture surfaces were examined to determine the sites of crack initiation and the areas of fast crack propagation. Previous studies of the macroscoplc features $(1-3)$ of fractures have shown that fast crack propagation generally occurs near the end of the failure sequence and produces ripples on the fracture surface. The ripples run roughly parallel to the direction of crack movement, taking a fan-shaped appearance, and point back to the area of crack initiation and slow growth. Shear lips form as the last step in fracture and, thus, are not associated with the early phases of fallure.

The fracture surfaces of the $5 / 8$-inch bolts shown in Figure 5 were almost totally covered by ripples in the fan-shaped orientation. The areas of crack initiation and slow growth, indicated by the ripples and the absence of shear 11p, were small and shallow, showing that the main crack had inftiated and/or grew slowly about $1 / 3$ around the clrcumference, while advancing only about a thread depth into the bolt, Figure 5 . The extended but shallow crack, and the roughness of the surface produced during the slow growth period, suggest that stress corrosion was responsible for crack formation early in the fallures. The large fraction of the surfaces covered by the ripples and the low amplitude of the ripples indicated a high applied stress durlng fallure.

The fracture surfaces of bolts $4 \mathrm{~A}$ and $4 \mathrm{~B}$ appeared very similar to the fracture surfaces of bolt lA (Figure 5) even though the bolts fractured in different places (see p. 5).

The fracture surface of the $3 / 4$-inch bolt was generally similar to the surfaces just described, except for the relatively larger area covered by the in-service fracture, Figure 6 . The area of in-service fracture (dark area) was rough and generally featureless, suggestive of a stress-corrosion crack. The greater roughness (compare with Figure 5) and the fact that the crack had arrested long enough for the black fllm to form by general surface corrosion both indicate that the applied stress was low. The ripples produced during removal of the bolt are typical of fast fracture in this material in the hardened condition and compare well with simllar features observed in the falled 5/8inch bolts.

None of the areas of crack initiation exhibited any of the macroscopic features characteristic of fatigue fallures. At first glance, the "half-moon" mark about midway through bolt 2B (Figure 5) may appear to be a fatigue feature. Such an interpretation is discounted, however, by the morphology and excellent 
definition of the features surrounding the "half-moon" mark. For example, ripples were clearly formed and continuous across the "half-moon" mark; and the surface inside the "half-moon" contained ripples, instead of being smooth as would have been the case for a fatigue fracture. The "half-moon" mark was probably caused by a change in temperature or stress during the brief period of crack propagation.

The fracture surfaces were replicated for electron microscopic examination by the cellulose acetate-carbon technique. Electron micrographs are shown in Figure 7. Microscoplcally the fracture surfaces were composed largely of various sized dimples, indicating ductile rupture, and some "orange peel" and irregular microcracking, which are evidence of stress corrosion. These fractographic features showed that the fractures had occurred by tensile rupture. The low ductility suggested by some of the features, secondary cracking and discontinuous cleavage, may have been caused by the plane strain conditions set up by the notch effect of the threads and the low fracture toughness of highly hardened 17-4 PH. Detalled searches revealed no microscopic arrest lines characteristic of fatigue.

The fractures of bolts $1 \mathrm{~A}$ and $2 \mathrm{~B}$ and the 3/4-inch bolt were sectioned approximately parallel to the ripples and examined metallographically. The fracture surfaces were smooth and almost totally transcrystalline across the fracture surfaces of the 5/8-inch bolts and the light area of the 3/4-inch bolt, Figure 6 . In contrast, the in-service part of the $3 / 4$-inch fracture surface was much rougher and exhibited more intercrystalline fracture. Many comparatively short, branching cracks orlented approximately $90^{\circ}$ to the surface were observed in the 5/8-inch bolts and the in-service part of the 3/4-inch bolt, Figure 6 .' These cracks were transcrystalline and intercrystalline, and were the same average length (depth) from one side of the bolt to the other. These secondary cracks probably formed by stress corrosion crackIng from residual quenching stresses after complete fallure of the bolts. These observations confirmed the results of the macrofractography, namely that most of the main fracture occurred during fast tensile fracture. 

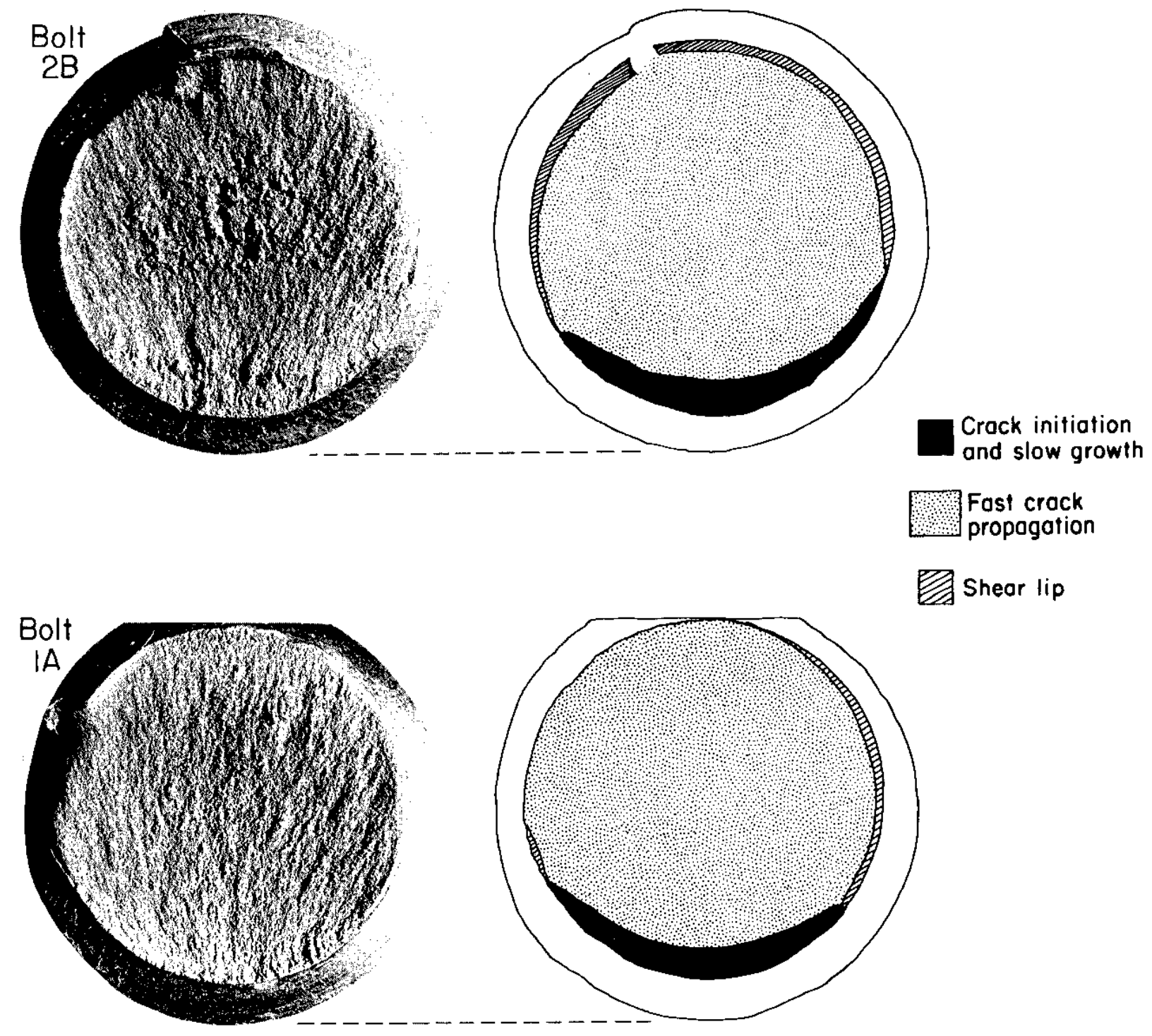

Shear lip

FIG. 5 FRACTURE SURFACES OF FAILED $5 / 8-$ INCH BOLTS

Ripples point to the area of crack initiation 
PROFILE OF FRACTURE PRODUCED DURING REMOVAL OF BOLT
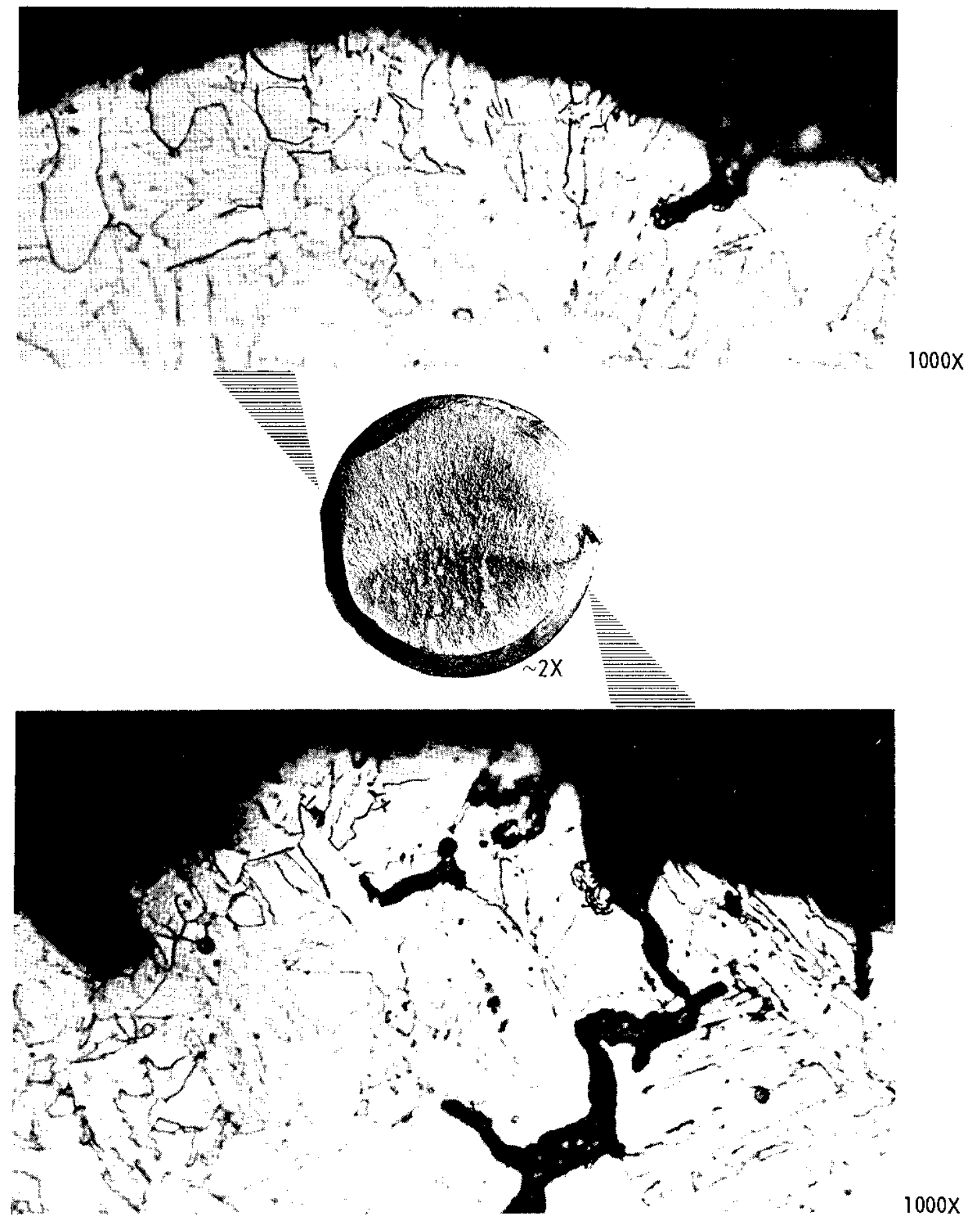

PROFILE OF FRACTURE PRODUCED BY STRESS CORROSION DURING HWCTR OPERATION

FIG. 6 FRACTURE SURFACES OF FAILED 3/4-INCH BOLT 

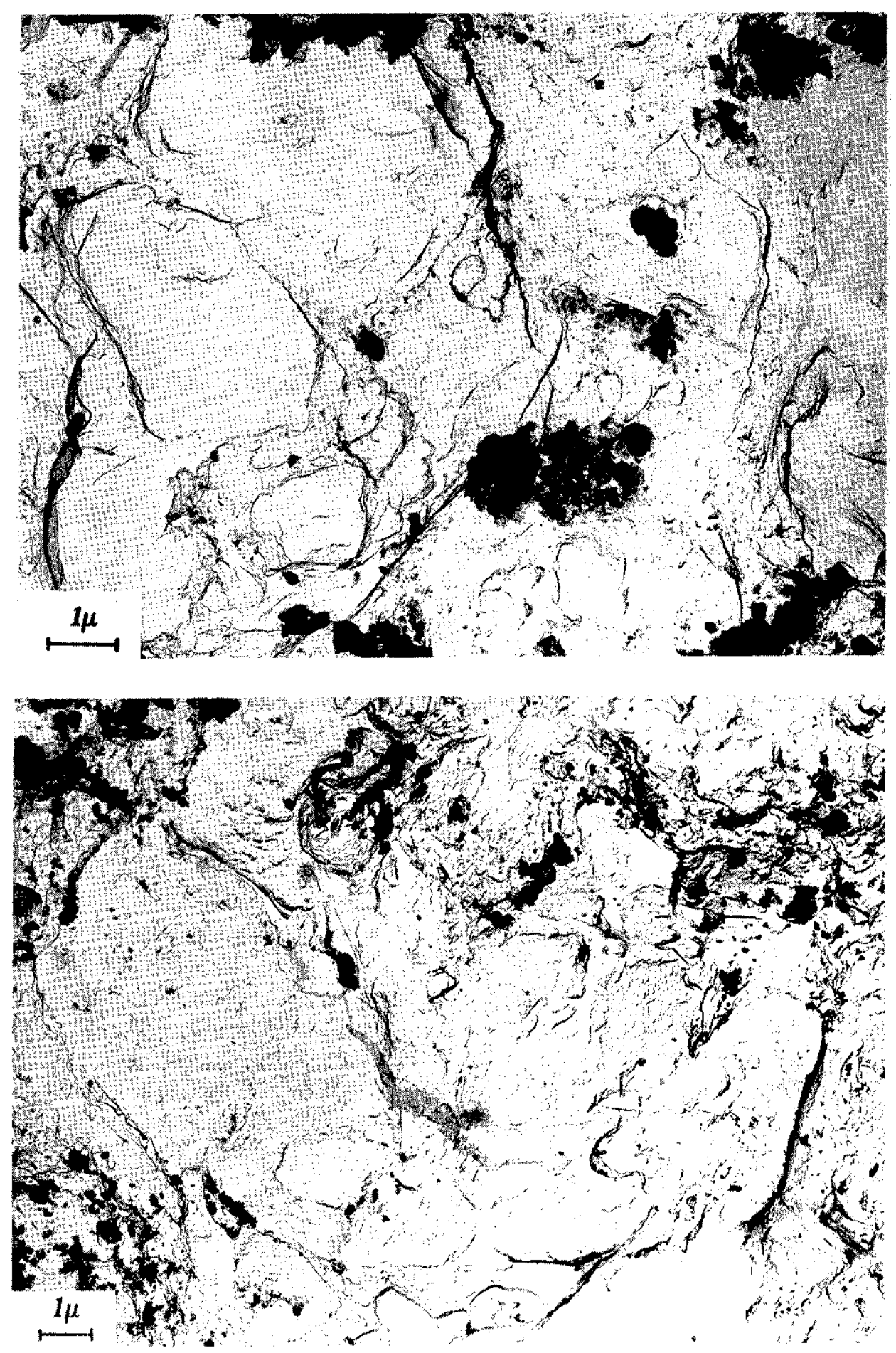

FIG. 7 DIMPLED RUPTURE AND INTERGRANULAR FRACTURE IN $5 / 8$-INCH BOLTS Large areas of the fracture surfaces were covered by corrosion products (black spots) and small pits from general surface corrosion after failure 
The chemical composition of bolts $1 A$ and $2 B$ was determined spectrographically and found to meet Armco steel speciflcations for the major elements except possibly chromium. Results are given in the accompanying Table $I$. The indicated chromium content of each bolt was marginally lower than the specifled value, but this factor is not belleved to be significant. According to vacuum fusion analyses, the hydrogen contents were below $1 / 2 \mathrm{ppm}$.

TABLE I

Chemicar Composition of 5/8-1nch Bolts

\begin{tabular}{|c|c|c|c|}
\hline \multirow[b]{2}{*}{ Element } & \multicolumn{3}{|c|}{ Composition, we1ght percent } \\
\hline & $\begin{array}{c}\text { Armeo } \\
\text { Spec1fioation (4) }\end{array}$ & $\frac{\text { Spectrograph1c }}{\text { BoIt 2B }}$ & $\frac{\text { Determination }}{\text { Bolt IA }}$ \\
\hline Copper & $3-5$ & 4 & 4 \\
\hline Chromium & $15.5-17.5$ & 13 & 14 \\
\hline Nickel & $3-5$ & 4 & 4 \\
\hline Manganese & $1.0 \max$ & - & - \\
\hline Iron & - & 78 & 77 \\
\hline $\begin{array}{l}\text { Carbon, phosphorus, } \\
\text { sulfur, stlicon }\end{array}$ & $1.14 \max$ & - & - \\
\hline $\begin{array}{l}\text { Columblum and } \\
\text { tantalum }\end{array}$ & $0.15-0.45$ & otal & $\overline{99}$ \\
\hline
\end{tabular}

The hardness of the bolts was measured on cross sections near the bolt head and near the threads. The hardness of both falled and unfalled 5/8-inch bolts and the falled 3/4-inch bolt was greater than the specified level of Rockwell $C$ 34, ( $\left.R_{c} 34\right)$ and varled between $R_{c} 39$ and 44, Table II. The hardness of an unfailed 3/4-inch bolt was $R_{c} 33$, a typical hardness for bolts heat treated to the H1100 condition as required in the HWCTR specifications. These data show that all the $5 / 8$-inch bolts and at least the failed 3/4-inch bolt had been annealed for precipitation hardening at about $925^{\circ} \mathrm{F}$, rather than at $1100^{\circ} \mathrm{F}$. As a result, the bolts in the $H 925$ condition were stronger than specifled, but were also highly susceptible to stress corrosion cracking. (5) 
TABLE II

Hardness of Bolts

\begin{tabular}{|c|c|c|}
\hline \multicolumn{2}{|l|}{ S1ze } & \multirow{2}{*}{$\frac{\text { Hardness, } R_{C}}{43-44}$} \\
\hline $5 / 8$ in., four un & alled & \\
\hline $5 / 8$ in., falled & $\left\{\begin{array}{l}1 \mathrm{~A} \\
2 \mathrm{~B} \\
4 \mathrm{~A} \\
4 \mathrm{~B}\end{array}\right.$ & $\begin{array}{l}41 \\
39 \\
41 \\
43\end{array}$ \\
\hline $3 / 4 \mathrm{in}$. , one unf & $11 e d$ & 33 \\
\hline $3 / 4$ in., one $\mathrm{fa}$ & & 41 \\
\hline
\end{tabular}

(a) Armco specified (4) hardness for H1200 is $R_{\mathrm{c}} 34 ; \mathrm{H} 1025,38$; and $\mathrm{H} 925,42$.

Subsequent evaluation of stressed corrosion specimens from HWCTR have confirmed the high susceptibility of the fully hard 17-4 PH alloy to cracking in the HWCTR environment. (6) out of ten stressed bend specimens of 17-4 PH alloy with different treatments, the three specimens with hardness above $R_{c} 40$ failed during exposure in HWCTR. The comparison of hardness with failure experience is presented in Table III.

\section{TABLE III}

Behavior of Stressed 17-4 PH Stainless Samples in HWCTR

(Exposure: $D_{2} O$ maintained at $p D$ of $10.7 \pm 0.5$ with

L $10 \mathrm{H}$, temperature during operation about $240^{\circ} \mathrm{C}$,

temperature during shut-down about $25^{\circ} \mathrm{C}$ )

\begin{tabular}{|c|c|c|}
\hline Condition when Placed in Test & $\begin{array}{c}\text { Hardness } \\
\text { After Test, } \\
R_{\mathrm{c}} \\
\end{array}$ & $\begin{array}{l}\text { Behavior } \\
\text { in the } \\
\text { HWCTR }\end{array}$ \\
\hline $\begin{array}{l}\text { Cold worked } 48 \% \text {, annealed } 8 \text { hours } \\
\text { at } 1100^{\circ} \mathrm{F}\end{array}$ & $\begin{array}{l}30 \\
30\end{array}$ & $\begin{array}{l}\text { OK } \\
\text { OK }\end{array}$ \\
\hline Annealed 8 hours at $1100^{\circ} \mathrm{F}$ & $\begin{array}{l}26 \\
25\end{array}$ & $\begin{array}{l}\text { OK } \\
\text { OK }\end{array}$ \\
\hline $\begin{array}{l}\text { Cold worked } 48 \% \text {, annealed } 1 \text { hour } \\
\text { at } 900^{\circ} \mathrm{F}\end{array}$ & $\begin{array}{l}42 \\
39\end{array}$ & $\begin{array}{l}\text { Falled (a) } \\
\text { OK }\end{array}$ \\
\hline Annealed 1 hour at $900^{\circ} \mathrm{F}$ & $\begin{array}{c}32 \\
30 \\
43 \\
\text { (Presumed > 40) }\end{array}$ & $\begin{array}{c}\text { OK } \\
\text { OK } \\
\text { Failed (b) } \\
\text { Falled (c) }\end{array}$ \\
\hline
\end{tabular}

(a) Fallure discovered after total exposure of 1000 days to $D_{2} O$ atmosphere in reactor gas space, of which 400 days were at operating temperature.

(b) Fallure discovered after total exposure of 65 days to $\mathrm{H}_{2} \mathrm{O}$ atmosphere plus 1000 days in $D_{z} \mathrm{O}$ atmosphere in reactor gas space, of which 400 days were at operating temperature.

(c) Fallure discovered after exposure of 65 days in $\mathrm{H}_{2} \mathrm{O}$ plus 535 days in $\mathrm{D}_{2} \mathrm{O}$ of which 276 days were at operating temperature. 


\section{ANALYSIS OF APPLIED STRESSES}

No record could be found that torque limlts were specifled or used in the installation of the 17-4 PH bolts. Thus, the initial stresses are unknown.

Calculations have shown that during HWCTR operation significant thermal stresses were generated in the bolts because the thermal expansion of the 304 stainless steel plates and washers was greater than that of the $17-4 \mathrm{PH}$ bolts. At $250^{\circ} \mathrm{C}$ the add1tional tensile stress that would be generated in the threaded part of the 5/8-inch bolts by thermal expansion was calculated to be $24,000 \mathrm{ps}$. The total stress would be further intensified by the notch effect of the threads, particularly at the first thread on the bolt shank. Peterson(7) reported a stress concentration factor of over 4 as determined by photoelastic measurements on a. Whitworth (English) thread, which is very similar in thread design to the UNC thread on the 5/8-inch bolts. Considering only thermal stresses, therefore, the minimum stresses in the bolts were approximately 96,000 psi. Th1s stress alone is enough to initiate stress-corrosion cracking in improperiy heattreated material. (5)

\section{CONCLUSIONS}

1. The stress-corrosion fallure of (four 5/8-inch and one 3/4inch) improperly heat-treated 17-4 PH bolts in a total of 42 bolts after 276 days ( 8 ) of operation in the gas stilling baffle of the HWCTR indicated the necessity of proper heat treatment of 17-4 $\mathrm{PH}$ for service in water-cooled reactors operating at temperatures of about $240^{\circ} \mathrm{C}$.

2. The detailed metallographic examination of the excessively hard failed bolts confirmed that stress-corrosion cracking had initiated the failures observed in the HWCTR.

3. The hardness of the falled bolts ranged from Rockwell $\mathrm{C} 39$ to $\mathrm{C} 43$, which indicated that they had been improperly heat treated. The bolts corresponded to the H 925 condition (aged at $925^{\circ} \mathrm{F}$ ) rather than the specified $\mathrm{H} 1100$ condition (aged at $\left.1100^{\circ} \mathrm{F}\right)$.

4. The excessively hard 17-4 PH alloy is known from its performance in other reactors to be susceptible to stresscorrosion cracking(5). This behavior was confirmed in a subsequent test of stressed test specimens in the HWCTR environment, which showed that specimens harder than RockwelI C-40 failed after about 400 days of operation. 
5. At the time that corrective measures were taken to replace the bolts in the stilling baffle - before the results of this investigation were avallable - the $5 / 8$-inch bolts were replaced with "Inconel" X (AMS-5667-F Heat Treatment) containing rolled threads, and the $3 / 4-1$ nch bolts were replaced with AISI 4140 steel (ASTM No. 193-62T). In the following eight months of operation before the HWCTR was shut down, during which the reactor accumulated 126 operating days, the replacement bolts operated satisfactorily. Reference 9 gives detalls of the corrective measures. 


\section{ACKNOWLEDGMENT}

The author wishes to thank M. R. Louthan, Jr. for the electron microscopic examination.

\section{REFERENCES}

1. F. R. Larson and F. L. Carr. "How Failures Occur... Topography of Fracture Surfaces." Metal Progress 85, No. 2,74 (1964).

2. F. R. Larson and F. I. Carr. "How Fallures occur.... Experiences in the Field." Metal Progress 85, No. 3, 109 (1964).

3. R. M. N. Pelloux. "The Analysis of Fracture Surfaces by Electron Microscopy." Met. Eng. Qtrly. 5, 26 (Nov. 1965).

4. "Armco Precipitation Hardening Stainless Steels, "Product Data Bulletin, Armco Steel Corp., November 3, 1958.

5. M. C. Rowland and W. R. Smith, Sr. "Precipltation-Hardening Stainless Steels in Water-Cooled Reactors." Nucl. Eng. 7, 14 (1962).

6. J. M. McKibben. Corrosion of Equipment in the Heavy Water Components Test Reactor, USAEC Report DP-964, E. I. du Pont de Nemours \& Co., Aiken, S. C. (1965).

7. R. E. Peterson. Stress Concentration Design Factors. John Wlley and Sons, Inc., New York. (1953).

8. E. O. Kiger. Operational Summary of the Heavy Water Components Test Reactor USAEC Report DP-991, E. I. du Pont de Nemours \& Co., Aiken, S. C. (1966).

9. P. L. Gray. "In-Situ Repairs in the Heavy Water Components Test Reactor." Nucl. Appl. 2, 213 (1966). 